"Mircea cel Batran" Naval Academy Scientific Bulletin, Volume XX - 2017 - Issue 1

The journal is indexed in: PROQUEST / DOAJ / Crossref / EBSCOhost / INDEX COPERNICUS / DRJI / OAJI I

JOURNAL INDEX I I2OR / SCIENCE LIBRARY INDEX / Google Scholar I Academic Keys/ ROAD Open Access I

Academic Resources / Scientific Indexing Services / SCIPIO / JIFACTOR

\title{
TEST OF THE DETECTION CAPABILITIES OF A SIDE SCANNING SONAR MOUNTED ON AN AUV
}

\author{
Georgică SLĂMNOIU \\ Ovidiu RADU \\ Valerică ROȘCA \\ Roxana-Gabriela DAMIAN \\ George SURDU \\ Camelia PASCU \\ Elena CURCĂ \\ Adrian RĂDULESCU
}

Captain(N) Assoc. prof. dr. eng., Research Center for Navy, Constanța, România

Captain(N) Researcher $3^{\text {rd }}$ degree eng. , Research Center for Navy, Constanța, România

Commander Researcher $3^{\text {rd }}$ degree eng. , Research Center for Navy, Constanța, România

First lieutenant Researcher eng. , Research Center for Navy, Constanța, România

Captain Researcher $3^{\text {rd }}$ degree dr. eng. , Research Center for Navy, Constanța, România

Researcher $3^{\text {rd }}$ degree eng. , Research Center for Navy, Constanța, România

Researcher $3^{\text {rd }}$ degree dr. mat. , Research Center for Navy, Constanța, România

Assistant, Research Center for Navy, Constanța, România

\begin{abstract}
Autonomous underwater vehicle (AUV) a.k.a. underwater drones are subsea vehicles which operate in the underwater environment independently of direct human input. There is a growing interest in underwater data collection by using autonomous underwater vehicles within the oceanographic research community. In this paper, the Iver 2 AUV is examined to accomplish accurate side-scan data while executing well planned missions. Therefore, this papers goal is to collect and process underwater data using the Iver2 AUV configured by the Research Center for Navy and built by Ocean Server during the underwater and surface missions.
\end{abstract}

Keywords: AUV (autonomous underwater vehicle), side-scan sonar, detection probability

\section{Introduction}

The AUV has a main role for missions of detection, localization, tracking and identification of risk factors located on the sea bottom. Operating in rather large areas it provides a high coverage rate at spatial and temporal resolutions that are not otherwise attainable. At the same time, the efficiency of an AUV is very high when compared to the costs and the duration of measurements. The information gathered should allow the operators to analyze:

- the presence on the sea bottom of mines or improvised explosive devices;

- the presence of submerged structures that can pose a risk of accident or can influence the underwater environment.

The advantages of using an autonomous underwater vehicle when compared to other equipment types or divers are:

- it can be used for classification and identification of suspicious objects;
- it has good maneuverability;

- it is a development platform that can be fitted with a large variation of sensors and instruments tailored for each particular mission;

- relatively long mission deployment time while achieving significant resources savings (fuel);

- human operators can safely stay out of the action range of the risk factor.

II. Characteristics of the autonomous underwater vehicle and of the side scanning sonar fitted to it

\section{A. Vehicle specifications}

AUV main characteristics are presented in table 1.

In the front section of the platform there are the following components (see figure 1):

- pressure sensor - is used for depth measurement;

- magnetic compass - used for direction and rotation around the vertical axis;

- three-axes accelerometer - is used for pitch, roll and rotation around the horizontal axis. 
"Mircea cel Batran" Naval Academy Scientific Bulletin, Volume XX - 2017 - Issue 1 The journal is indexed in: PROQUEST I DOAJ / Crossref / EBSCOhost / INDEX COPERNICUS I DRJI / OAJI I JOURNAL INDEX I I2OR / SCIENCE LIBRARY INDEX / Google Scholar I Academic Keys/ ROAD Open Access I Academic Resources / Scientific Indexing Services / SCIPIO I JIFACTOR

In the center section there are currently installed (see figure 1):

- energy power sources (lithium batteries);

- navigation control system;

- system for sensor management, data reception and processing.

In the cylindrical area of the body, towards the rear half is the antenna block (GPS/WiFi), navigation position lights and a connector for recharging the batteries.

The navigation control system and the sensor management system are each a pc-type CPU unit (PC104: 3,6" x 3,8" - 91,44 x 96,52 mm) running Windows ${ }^{\circledR}$ XP Embedded with adequate memory resources. Due to the computing power required by

\begin{tabular}{|l|l|}
\hline Items & Specification \\
\hline Vehicle weight in air & $\approx 25 \mathrm{~kg}$ \\
\hline Energy and endurance & $\min .8 \mathrm{~h} / 2 \mathrm{Nd}$ \\
\hline Speed: & max. 4 Nd \\
\hline Surface navigation & GPS \\
\hline Underwater navigation & Magnetic compass \\
\hline Payload & Side-scan sonar \\
\hline Maximum immersion depth & $100 \mathrm{~m}$ \\
\hline Connectivity & WiFi $802.11 \mathrm{~g}$ (while at surface). \\
\hline
\end{tabular}

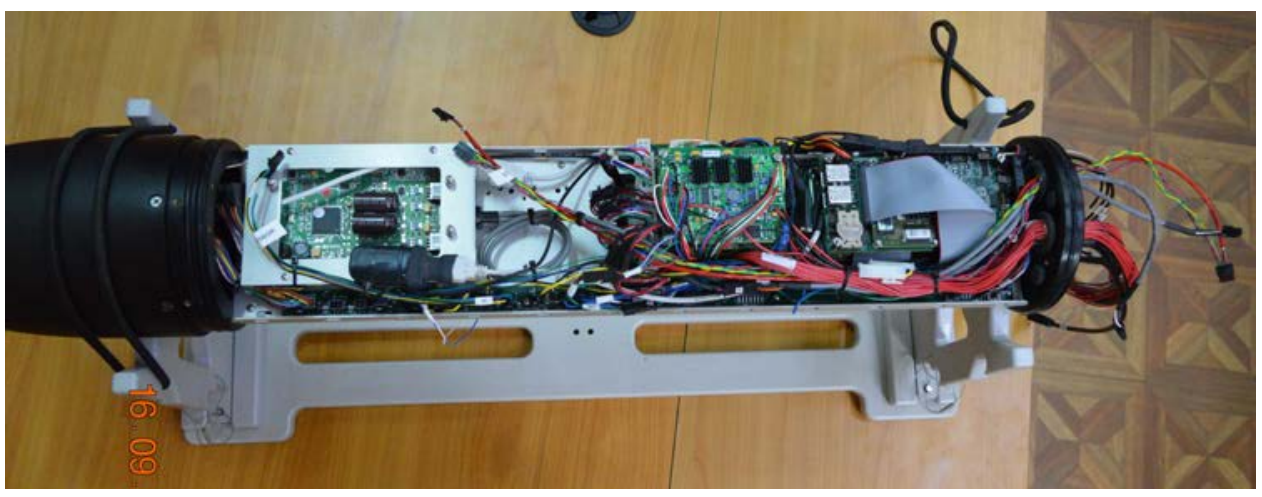

Figure 1.- Internal Layout of Iver2

The Navigation control system is used for running the „Underwater Vehicle Console”, software that allows:

- Verification of the vehicle functions (and surface navigation) while in manual debug mode

- Definition of the platform parameters and mission planning: mission planning; safety rules definition;sensor functional configuration definitions

- Verification of sensors and instruments functioning and viewing of mission recordings.

The transmission of data acquired during a mission and programming of the vehicle is done using a wireless 802.11g network. The console for command and mission planning includes a wireless $802.11 \mathrm{~g}$ adapter and an the side scanning sonar, the AUV also has installed a third data processing unit for the sonar. 
"Mircea cel Batran" Naval Academy Scientific Bulletin, Volume XX - 2017 - Issue 1

The journal is indexed in: PROQUEST I DOAJ / Crossref / EBSCOhost / INDEX COPERNICUS I DRJI / OAJI I JOURNAL INDEX I I2OR / SCIENCE LIBRARY INDEX / Google Scholar I Academic Keys/ ROAD Open Access I

Academic Resources / Scientific Indexing Services / SCIPIO / JIFACTOR

in table or other file formats, for analysis and validation (removal of extreme / aberrant values). The sonar data recordings can also be integrated on the maps and the application also allows the use of previous sonar recordings as maps for planning future missions.

\section{B. Side-scan sonar specifications}

Currently the platform has a side scanning sonar (see fig. 2) with specific characteristics presented in table 2.

Considering that sonar systems (side scanning, multibeam, synthetic aperture) can provide centimeter resolution and also considering the importance of the speed of area survey, when we selected the sensors for the underwater platform we considered it would be more useful to first install a sonar system rather a video camera. The sonar systems typically installed on AUVs are multi-beam or sidescanning. A comparison of the various criteria for use of such sonars on AUVs is presented in table 3.
Analyzing the data in the previous table and also considering:

- The specificity of the western Black Sea area (from the point of view of depths, thermal and saline)

- Operation performances of the AUV (maximum immersion depth 100m)

- Other AUV's standard functions (side scanning sonar)

- Necessity of conducting some marine environment surveys with low resources (human, material, temporal and financial).

We find that the AUV used by RCN has an optimal configuration (side scanning sonar) for use in activities of discovery of underwater targets like arine mines, torpedoes or IED.

\begin{tabular}{|l|l|}
\hline Item & Specification \\
\hline Frequency: & $450 \mathrm{kHz}$ center frequency $(430-470 \mathrm{kHz})$ \\
\hline Pulse duration: & $400 \mu \mathrm{s}$ \\
\hline Signal processing: & Compressed pulse $(\mathrm{CHIRP}$ pulse $)$ \\
\hline Hydro-acoustic sensors: & 2 side sensors attached to the AUV \\
\hline Dimensions (Length $\mathrm{x}$ width $\mathrm{x}$ height): & $432 \times 41 \times 18 \mathrm{~mm}$. \\
\hline Directivity characteristic of each sensor $(\mathrm{VxO}):$ & $60^{\circ} \times 0,5^{\circ}(-3 \mathrm{~dB}) ;$ \\
\hline Coverage area: & $1 \mathrm{~m} \ldots .100 \mathrm{~m}$ on channel \\
\hline Emission power level: & $<210 \mathrm{~dB}$ rel. $1 \mu \mathrm{Pa} / 1 \mathrm{~m}$. \\
\hline
\end{tabular}

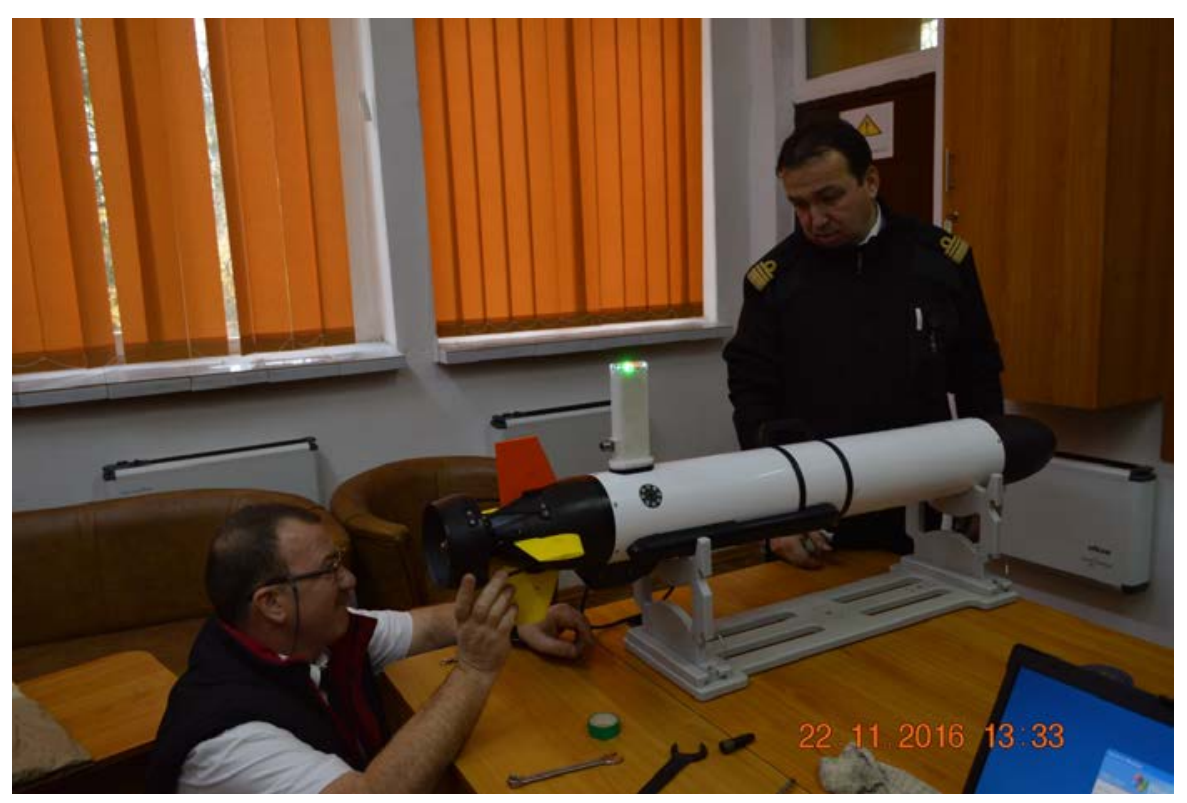

Figure 2.- Iver2 AUV with side-scan sonar 
"Mircea cel Batran" Naval Academy Scientific Bulletin, Volume XX - 2017 - Issue 1

The journal is indexed in: PROQUEST I DOAJ / Crossref / EBSCOhost / INDEX COPERNICUS I DRJI / OAJI I JOURNAL INDEX I I2OR / SCIENCE LIBRARY INDEX / Google Scholar / Academic Keys/ ROAD Open Access I Academic Resources / Scientific Indexing Services / SCIPIO / JIFACTOR

Table 3 - Advantages and limits of use of side scanning sonars and of multi-beam sonars

\begin{tabular}{|c|c|c|c|}
\hline $\begin{array}{l}\text { Sonar } \\
\text { type }\end{array}$ & Advantages & Limits & Comments \\
\hline Side scan & $\begin{array}{l}\text { - Is the main tool for shallow } \\
\text { water cartography, it can } \\
\text { capture a much larger bottom } \\
\text { area than the multi-beam (for } \\
\text { depths }<30 \text { m). } \\
\text { - Is the only technology } \\
\text { capable of producing } \\
\text { continuous image strips of } \\
\text { the sea bottom for all depths. } \\
\text { - the side-scan has no } \\
\text { practical limits when } \\
\text { considering the scanning } \\
\text { angle while the multi-beam } \\
\text { has a fixed angle sector. }\end{array}$ & $\begin{array}{l}\text { - Can be used only partially } \\
\text { for bathymetry operations. }\end{array}$ & $\begin{array}{l}\text { - is a compromise between } \\
\text { sector width, resolution, } \\
\text { scanning speed and financial } \\
\text { resources needed. } \\
\text { - At high frequencies can } \\
\text { provide excellent resolutions } \\
\text { but with high environment } \\
\text { attenuation. } \\
\text { - Resolution is better than } \\
\text { that of multi beam systems } \\
\text { but careful calibration must } \\
\text { be used to account for the } \\
\text { distortions caused by the } \\
\text { sensor movement. }\end{array}$ \\
\hline $\begin{array}{l}\text { Multi } \\
\text { beam }\end{array}$ & $\begin{array}{l}\text { - Able to obtain very dense } \\
\text { track data and at the same } \\
\text { time provide acoustic } \\
\text { intensity data using the same } \\
\text { sensor. }\end{array}$ & $\begin{array}{l}\text { - Is less efficient in shallow } \\
\text { water }(<30 \mathrm{~m}) \text {. } \\
\text { - Long exploration time for } \\
\text { shallow water, the width of } \\
\text { the analyzed area is just } 3 \text { to } \\
5 \text { times the depth. } \\
\text { - Exploration results depend } \\
\text { very much on the data about } \\
\text { water bottom nature, } \\
\text { operator experience and } \\
\text { propagation parameters. }\end{array}$ & $\begin{array}{c}\text { - does not provide the } \\
\text { resolution and image details } \\
\text { that a side scanner can } \\
\text { provide. } \\
\text { - Interpretation of data is } \\
\text { much more complex and } \\
\text { takes longer. }\end{array}$ \\
\hline
\end{tabular}

III. Testing of the AUV with side scanning sonar in shallow waters

The tests were conducted in an area (see figure 3) where:

- Noise caused by naval traffic is low

- There are no large variations of the thermal and saline environment

- Positioning of the reference buoys and targets can be done easily and with relatively high accuracy

- Depth and bottom type are already known data.
The specificity of the testing area is given by:

- Naval traffic was only random occasional crossings of leisure craft to/from Limanu Harbour and RHIB boats belonging to SFOS

- There were no large variations in the thermal and saline (salinity around 19 PSU, surface temperature around $19-$ $\left.22^{\circ} \mathrm{C}\right)$

Depth of around $11 \mathrm{~m}$, bottom generally composed of peat and covered with mud, only in the southern area having some rocks.

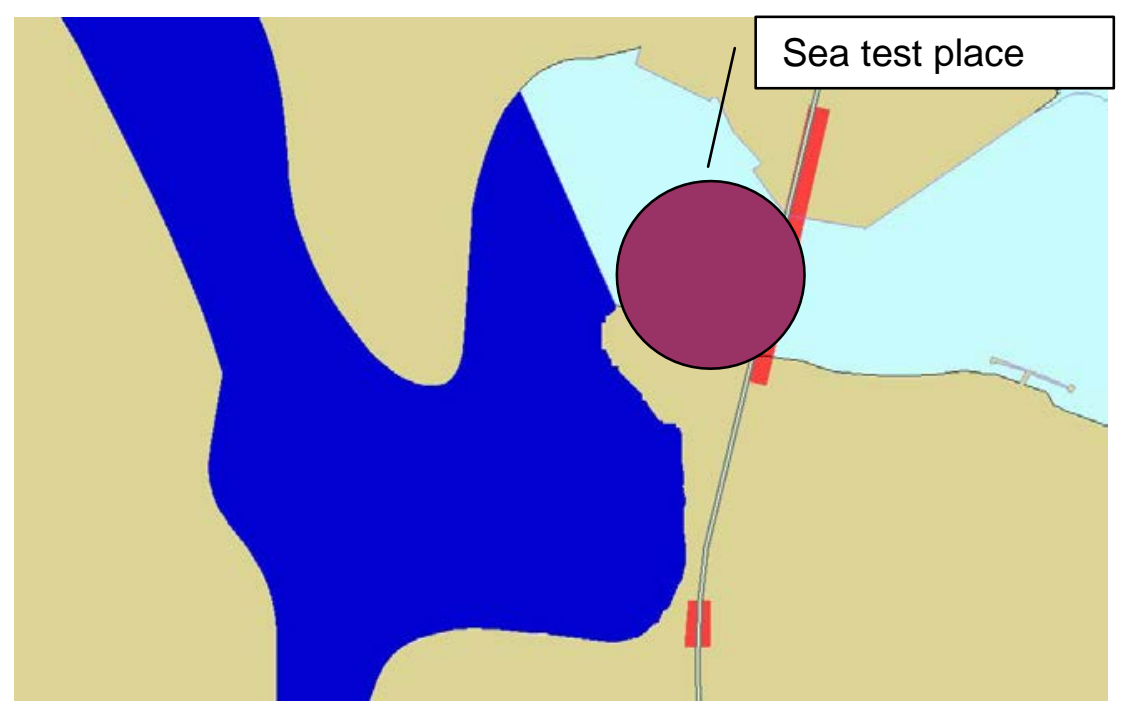

Figure 3 - Place where we conducted the sea tests 
"Mircea cel Batran" Naval Academy Scientific Bulletin, Volume XX - 2017 - Issue 1 The journal is indexed in: PROQUEST / DOAJ / Crossref / EBSCOhost / INDEX COPERNICUS / DRJI / OAJI I JOURNAL INDEX I I2OR / SCIENCE LIBRARY INDEX / Google Scholar / Academic Keys/ ROAD Open Access I Academic Resources / Scientific Indexing Services / SCIPIO I JIFACTOR

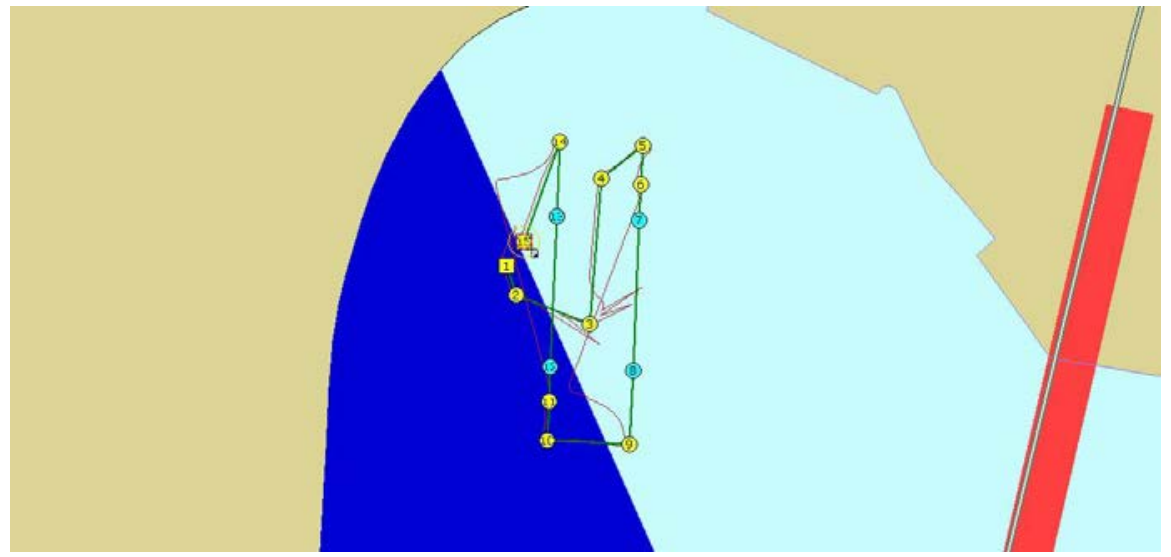

Figure 4 - Programmed path (with surface and immersion navigation) and the path actually travelled (red = deviations from the programmed path)

\section{A. Path deviations}

Due to the weather conditions (on surface - wind, in immersion - currents), the AUV had quite large deviations from the programmed path (see figure 4 and figure 5).

Of note is the fact that the missions were planned in such a way that the AUV is aligned on track when it sails on surface and has access to GPS (see figure 7).

\section{B. Oscillations of the platform while on surface and in immersion}

Of note is the fact that roll and pitch of the AUV is quite low and depth keeping is quite precise. Entering and exiting from immersion was quite rough but without too many oscillations of the platform at the end of the maneuver (see figure 6).

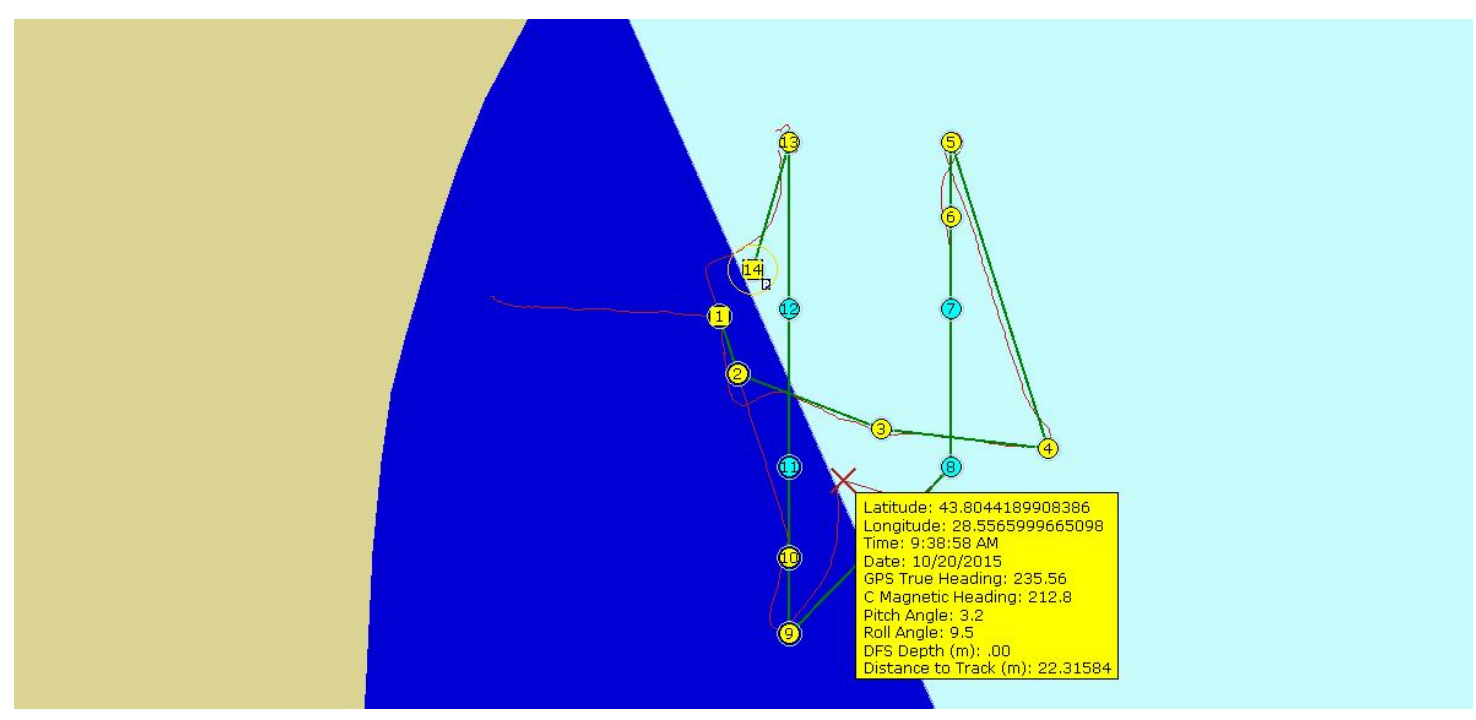

Figure. 5 - Path deviations 
"Mircea cel Batran" Naval Academy Scientific Bulletin, Volume XX - 2017 - Issue 1 The journal is indexed in: PROQUEST / DOAJ / Crossref / EBSCOhost / INDEX COPERNICUS / DRJI / OAJI I JOURNAL INDEX I I2OR / SCIENCE LIBRARY INDEX / Google Scholar / Academic Keys/ ROAD Open Access I Academic Resources / Scientific Indexing Services / SCIPIO / JIFACTOR
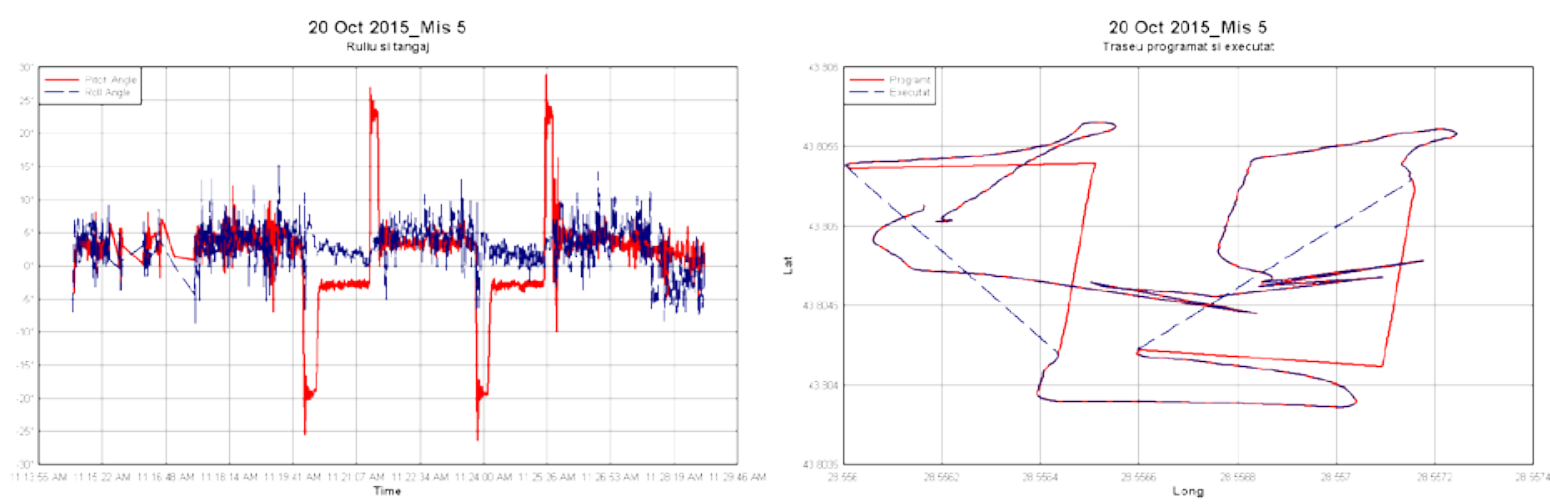

Figure 6 - Variations of path, roll and pitch of the AUV during track passage (SS= max. 1)

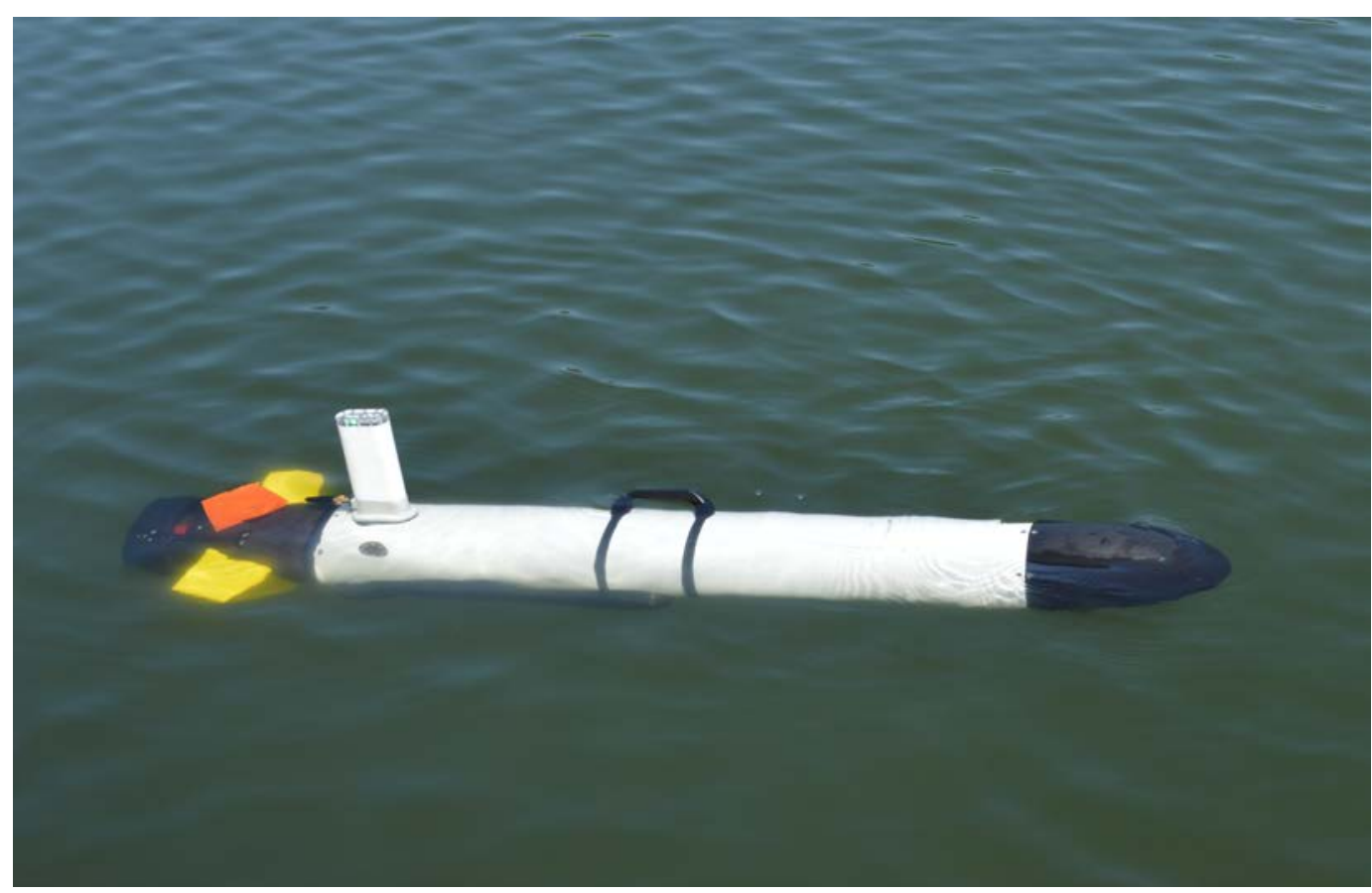

Figure 7- AUV on surface

\section{Sonar recordings}

Here we present sonar recordings overlaid on the planned mission path and details of this, idenfied contacts and recordings created by the specific software, Scanline. 
"Mircea cel Batran" Naval Academy Scientific Bulletin, Volume XX - 2017 - Issue 1 The journal is indexed in: PROQUEST / DOAJ / Crossref / EBSCOhost / INDEX COPERNICUS / DRJI / OAJI I JOURNAL INDEX I I2OR / SCIENCE LIBRARY INDEX / Google Scholar / Academic Keys/ ROAD Open Access I Academic Resources / Scientific Indexing Services / SCIPIO / JIFACTOR

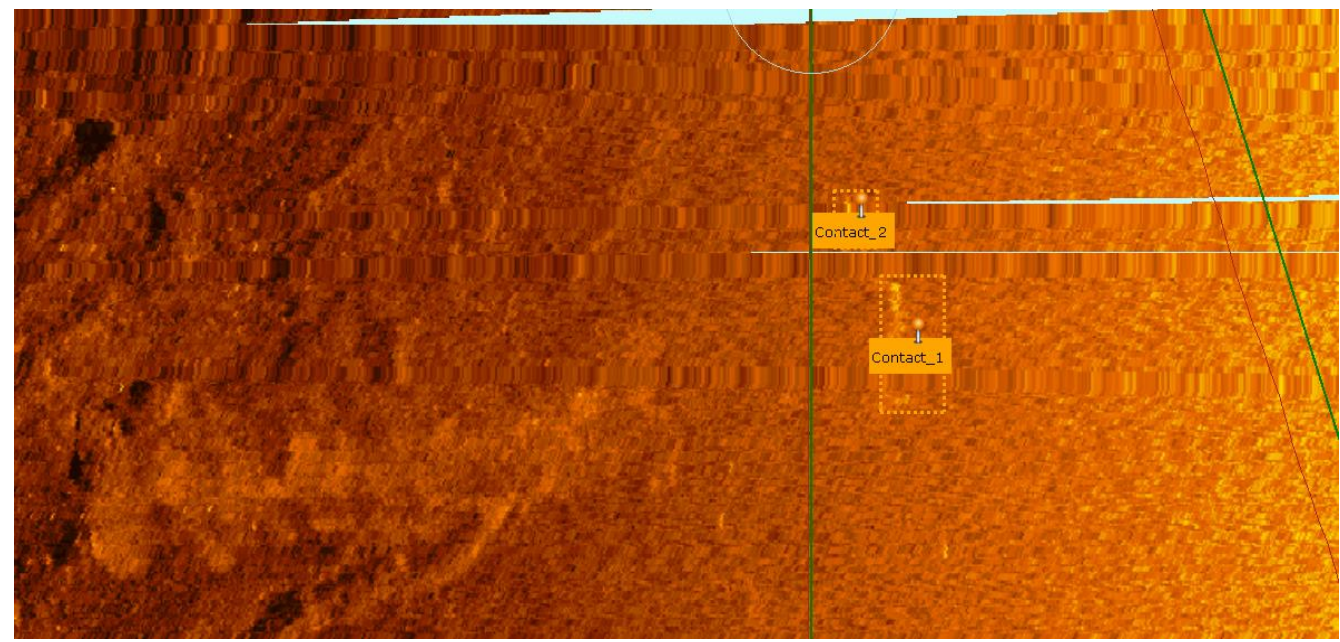

Figure 8 - Sonar contacts, mission 1

Details about the contacts can be obtained through operator interpretation of the data and this is why we consider that the experience is crucial when trying to obtain data as close to real as possible (see figure 8).

Contact_1 (see figure 9):

- Position of Contact: Latitude:

43.8047858200479 Longitude: 28.557099387344 - Size of Contact: Width(m):

0.3622783 Height(m): 1.233304

- Size of the selected area:

Width(m): 2.88 Height(m): 6.17

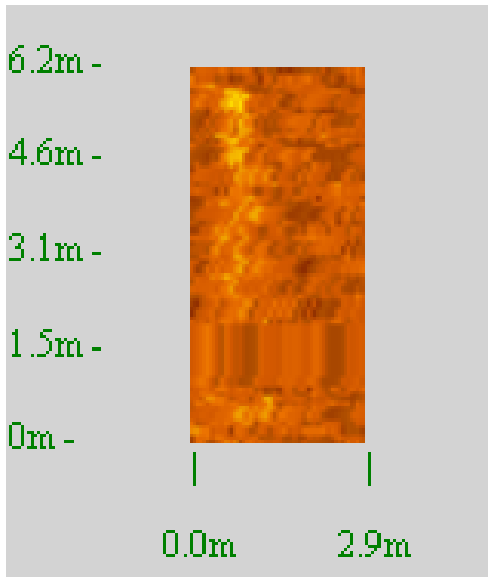

Figure 9 - Contact 1 Mission_1
Contact 2 (see figure 10):

- Position of Contact: Latitude: 43.8048365887958 Longitude:

28.5570673237462

- Size of Contact: Width(m): 0.2014776 Height(m): 0.9666433

- Size of the selected area: Width $(\mathrm{m})$ : 1.97 Height(m): 2.58

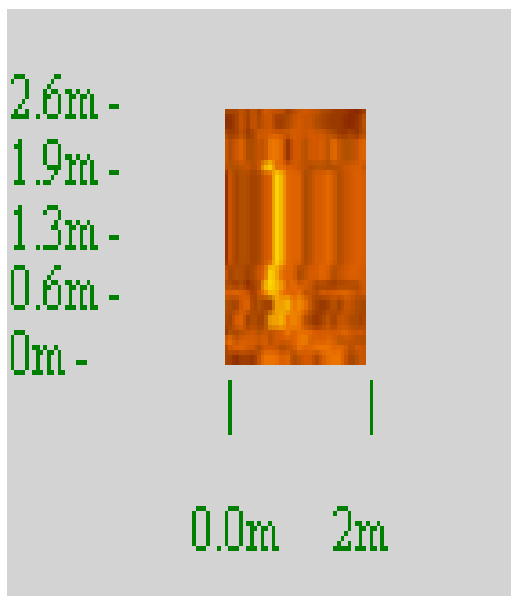

Figure 10 - Contact 2 Mission_ 
"Mircea cel Batran" Naval Academy Scientific Bulletin, Volume XX - 2017 - Issue 1

The journal is indexed in: PROQUEST / DOAJ / Crossref / EBSCOhost / INDEX COPERNICUS / DRJI / OAJI I

JOURNAL INDEX I I2OR / SCIENCE LIBRARY INDEX / Google Scholar I Academic Keys/ ROAD Open Access I

Academic Resources / Scientific Indexing Services / SCIPIO / JIFACTOR

Analyzing the conducted missions has shown that the sonar has remarkable performance, allowing that at 3-4 meters from bottom to be able to identify reduced dimension targets.

We find that the working frequency of the side scanning sonar is low enough so that it reduces propagation losses. Analyzing the characteristics of the side scanning sonar allows us to conclude that it has good performances (very good resolution, relatively low operating frequency).

\section{Evaluation of underwater target discovery capabilities by the side scanning sonar mounted on the AUV}

Analyzing the conducted missions we have the following:

- When sailing at surface the oscillations of the AUV are quite large and depend largely on the orientation in regard to waves, sa state, wind, etc.

- At surface, the pitch can have significantly larger values than roll, but this one is amplified during gyrations are irrelevant

- Sonar recordings during gyration of the vehicle

- Large height in relation to the bottom does not allow to distinguish small target details

- During surface navigation, GPS and magnetic compass data does not vary too much

- Various boats crossing though the scanning area will create major water turbulence which will generate some masked areas ('false targets') in the sonar recordings During the trials the AUV will operate in immersion, at depths of $5-20 \%$ of the depth to be explored. Of the collected data only modifications of the bottom reflective properties will be considered (rocky or muddy bottom), because the environment noise level - generated by the sea state or random vehicle traffic - has very small influences on the general sonar performances in the frequency band where it operates.

Theoretical evaluation of undenwater target discovery capabilities by the side scanning sonar mounted on the AUV has been conducted for the scenarios presented in table 4.

Characteristics are considered for a sea state with wind speed $<0.3 \mathrm{~m} / \mathrm{s}$ and wave height $0 \mathrm{~m}$.

Table 4-. Resistance and reactance values results

\begin{tabular}{|c|c|c|c|c|c|}
\hline \# & $\begin{array}{l}\text { Target strength } \\
{[\mathrm{dB}]}\end{array}$ & $\begin{array}{c}\text { Sonar immersion } \\
\text { depth }[\mathrm{m}]\end{array}$ & $\begin{array}{l}\text { Bottom depth } \\
{[\mathrm{m}]}\end{array}$ & $\begin{array}{l}\text { Sound speed } \\
\text { profile }\end{array}$ & Specific characteristics \\
\hline 1 & -20 & 30 & 50 & Feb. & $\begin{array}{c}\text { Sea state - SS 0 } \\
\text { Bottom nature - mixed rock and mud }\end{array}$ \\
\hline 2 & -20 & 40 & 50 & Summer & $\begin{array}{c}\text { Sea state - SS 0 } \\
\text { Bottom nature - mixed rock and mud }\end{array}$ \\
\hline 3 & -20 & 40 & 50 & Summer & $\begin{array}{c}\text { Sea state - SS 0 } \\
\text { Bottom nature }- \text { mixed rock and mud bottom } \\
\text { slope }+10 \%\end{array}$ \\
\hline 4 & -45 & 40 & 50 & Feb. & $\begin{array}{c}\text { Sea state - SS 0 } \\
\text { Bottom nature - mud }\end{array}$ \\
\hline 5 & -45 & 40 & 50 & Summer & $\begin{array}{c}\text { Sea state - SS 0 } \\
\text { Bottom nature }- \text { mixed rock and mud bottom } \\
\text { slope }+10 \%\end{array}$ \\
\hline
\end{tabular}

Following the simulations conducted, we have evaluated the target detection probability. The results of these evaluations, for scenarios presented in the previous table are presented in figures $11,12,13,14$ and 15 . 
"Mircea cel Batran" Naval Academy Scientific Bulletin, Volume XX - 2017 - Issue 1 The journal is indexed in: PROQUEST / DOAJ / Crossref / EBSCOhost / INDEX COPERNICUS / DRJI / OAJI I JOURNAL INDEX I I2OR / SCIENCE LIBRARY INDEX / Google Scholar / Academic Keys/ ROAD Open Access I Academic Resources / Scientific Indexing Services / SCIPIO / JIFACTOR

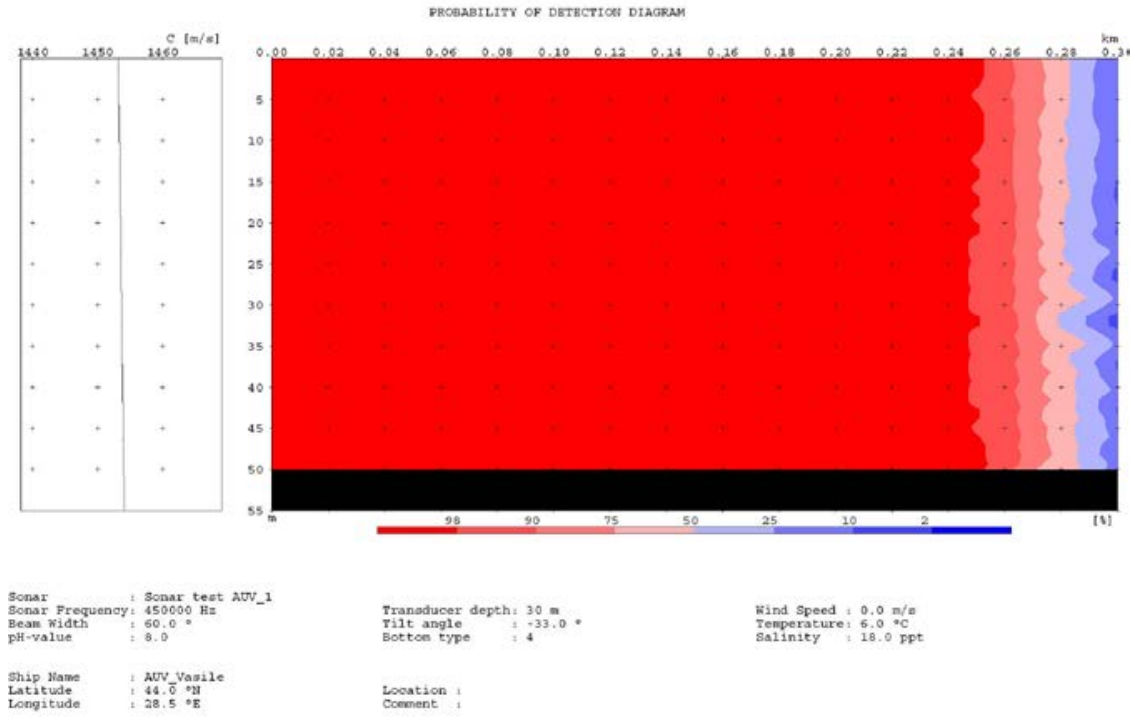

Figure 11 - Detection probability for scenario no. 1
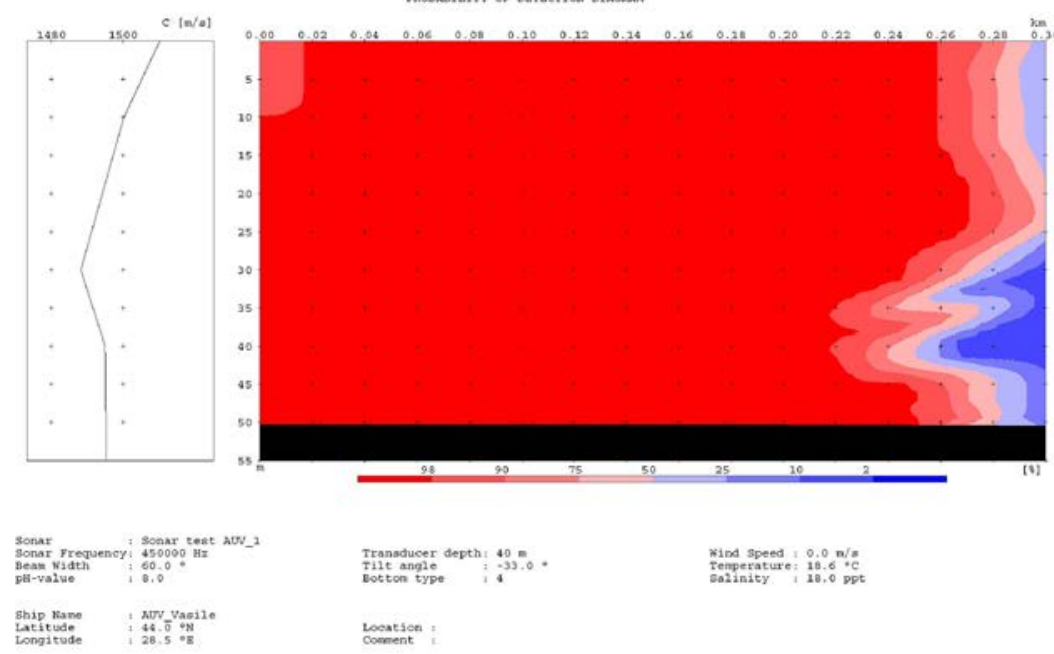

Figure 12 - Detection probability for scenario no. 2

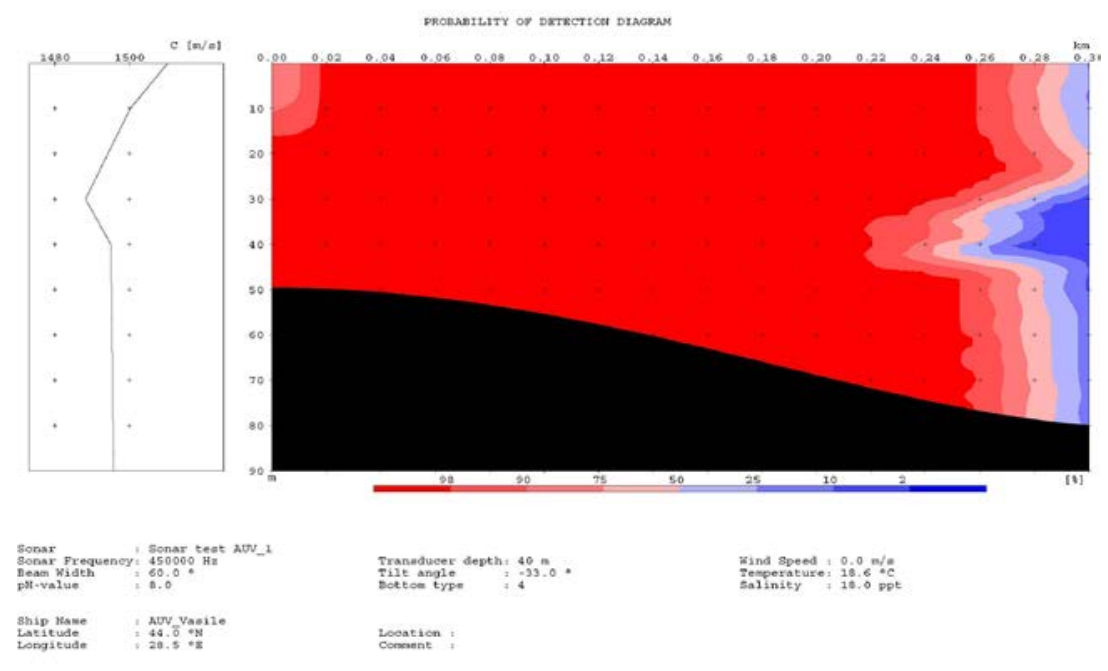

300 
"Mircea cel Batran" Naval Academy Scientific Bulletin, Volume XX - 2017 - Issue 1 The journal is indexed in: PROQUEST / DOAJ / Crossref / EBSCOhost / INDEX COPERNICUS / DRJI / OAJI I JOURNAL INDEX I I2OR / SCIENCE LIBRARY INDEX / Google Scholar I Academic Keys/ ROAD Open Access I Academic Resources / Scientific Indexing Services / SCIPIO I JIFACTOR

Figure 13 - Detection probability for scenario no. 3

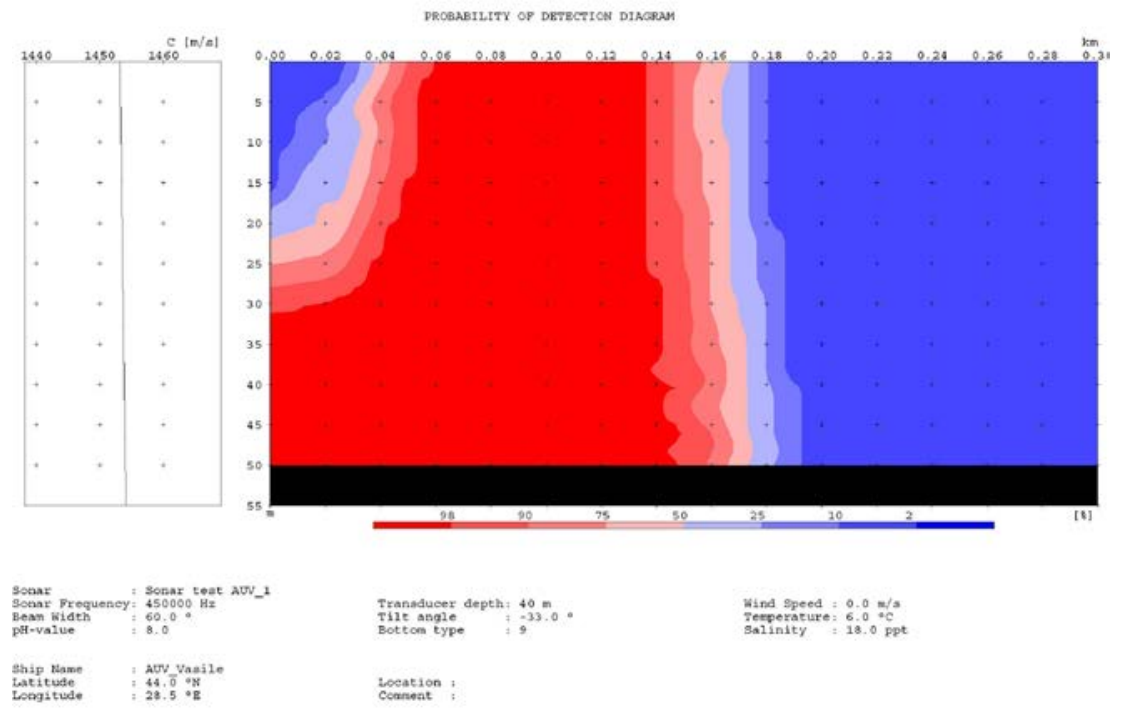

Figure 14 - Detection probability for scenario no. 4

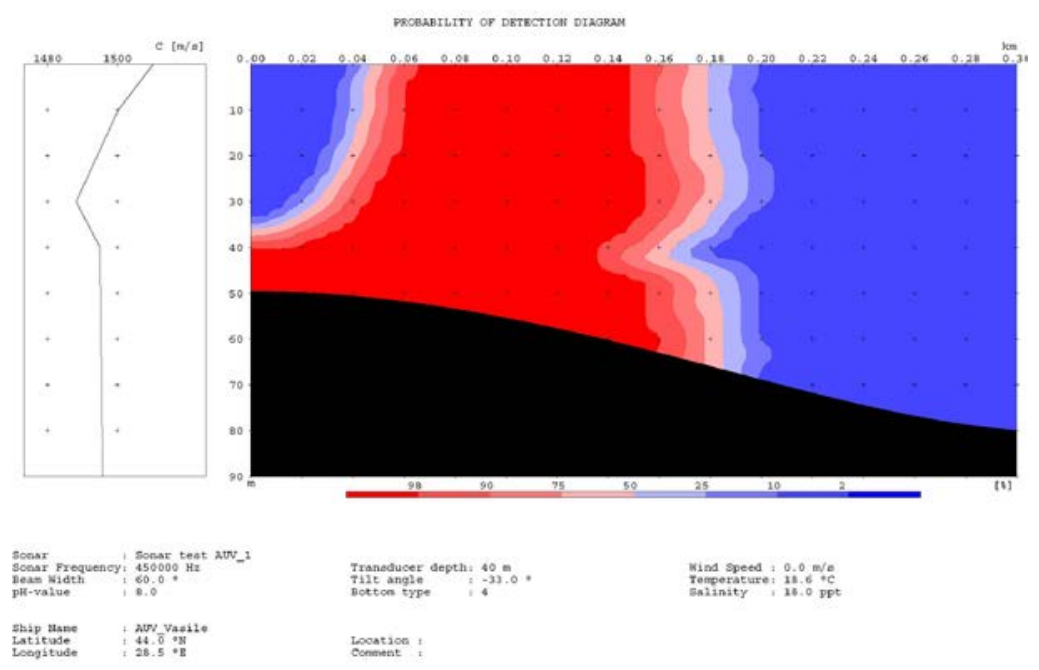

Figure 15- Detection probability for scenario no. 5

According to the simulation results we can state that:

- For TS = having high values (over $10 \mathrm{~dB}$ rel. $1 \mu \mathrm{Pa} / 1 \mathrm{~m})$ - the probability of discovery of the target is above $98 \%$ within the limit of the sonar maximum range (adjustable between 20 to $100 \mathrm{~m}$ ), no matter what environment conditions, bottom nature, depth and AUV activity conditions (immersions between 10 and $45 \mathrm{~m}$ )

- Adapting the AUV immersion to the sound speed profile and sea bottom profile allows us to increase the target detection probability within the limit of the maximum sonar range
- For targets with a very low TS (depending on the observation angle, dimensions/geometry or materials used for fabrication - under $-20 \mathrm{~dB}$ rel. $1 \mu \mathrm{Pa} / 1 \mathrm{~m}$ ) the discovery can be conducted with a reasonable probability (>90\%) on small distances and on the condition of adjusting very precisely the AUV immersion depth and maximum sonar distance to the sound speed profile and sea bottom profile. 
"Mircea cel Batran" Naval Academy Scientific Bulletin, Volume XX - 2017 - Issue 1 The journal is indexed in: PROQUEST / DOAJ / Crossref / EBSCOhost / INDEX COPERNICUS / DRJI / OAJI I JOURNAL INDEX I I2OR / SCIENCE LIBRARY INDEX / Google Scholar / Academic Keys/ ROAD Open Access I Academic Resources / Scientific Indexing Services / SCIPIO / JIFACTOR

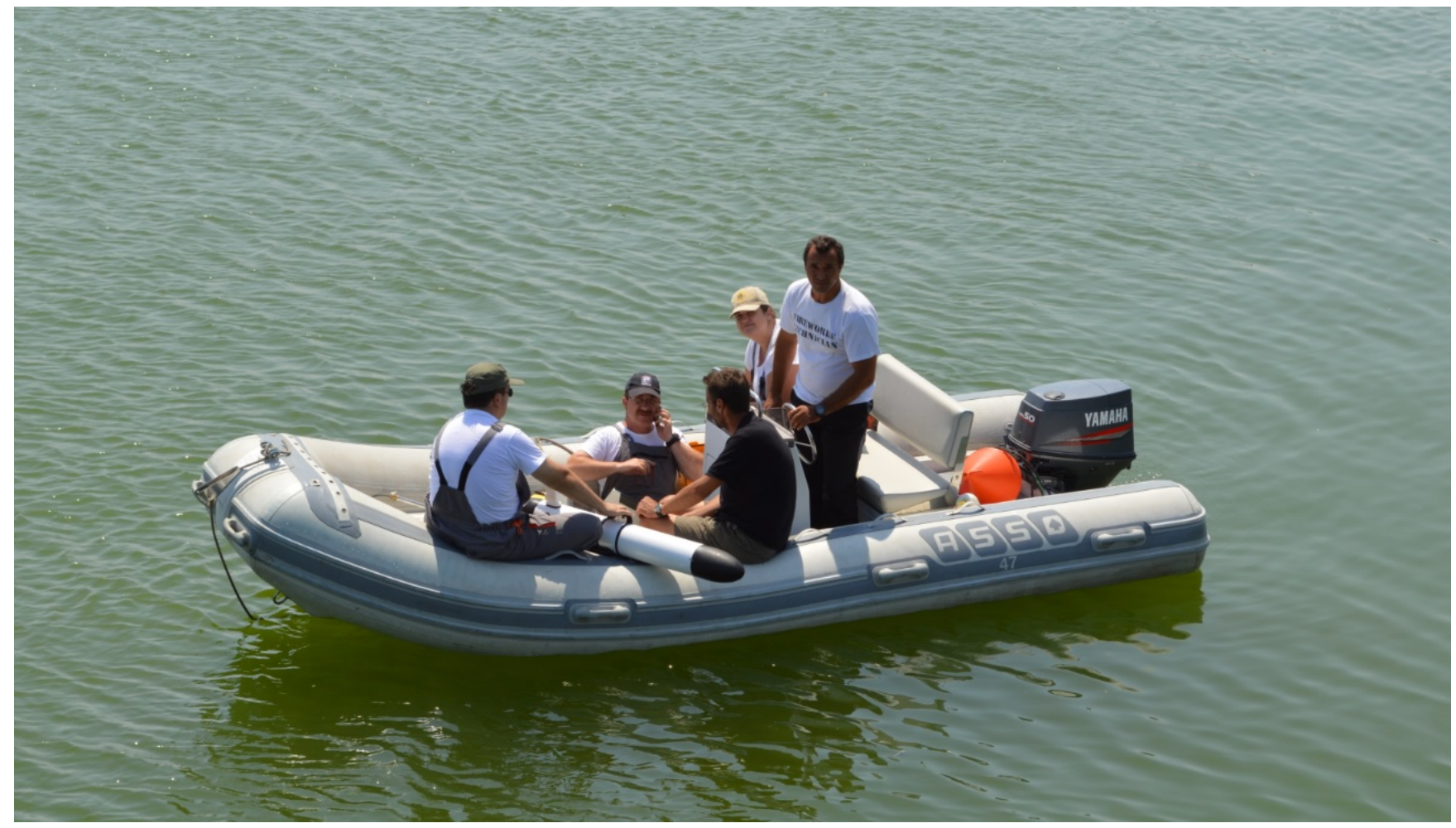

Figure 16 - Recoverd AUV

\section{Conclusions}

In missions that require just surface measurements the vehicle can track accurately the programmed path by compensating via data from GPS, magnetic compass and accelerometers the deviations caused by waves, sea currents, etc.

Figure 16 shoes the AUV recovery by boot using the Research Center for Navy manpower.

In submerged missions, as the vehicle lacks a Doppler Velocity Loch (DVL), adjusting the path deviations caused by sea currents was not possible to be done with a satisfying level of accuracy.

Entering/exiting from immersion of the AUV is quite rough, without major variations of the geographic position, allowing for an easier mission planning.

Depending on water density in the area where the mission is executed, we need to adjust the trim and floatability of the vehicle using ballast attached to the exterior of the central structure. Adjusting these is done through multiple attempts.

It is useful to measure the sound speed velocity in the mission area and to use the value recorded for this parameter in the mission planning software.

Evaluation of the target discovery capabilities must be done with good knowledge of the local hydrometeorological factors that can have an influence on the activity (speed velocity profile with depth, naval traffic intensity, sea bottom specific characteristics, etc.)

\section{Bibliography}

[1] „Acoustic Ambient Noise in the Ocean: Spectra and Sources”, JASA, 1962.

[2] „Data Base Description for the Master Generalized Digital Environmental Model (GDEM)”, Naval Oceanographic Office, 1996.

[3] „Beaufort Scale”, Royal Meteorological Society.

[4] „Beaufort Scale”, Encyclopædia Britannica.

[5] „Beaufort wind force scale”. Met Office.

[6] Blondel, P., „Handbook of sidescan sonar”, Wiley, Chichester, 2009.

[7] Button, Robert W., Kamp, John, ş.a., „A Survey of Missions for Unmanned Undersea Vehicles”, RAND Corporation, USA, 2009.

[8] Dahl, Peter H., „Underwater Ambient Noise”, Applied Physics Laboratory, University of Washington, Seattle, Washington, Acoustics Today, 2007. 
"Mircea cel Batran" Naval Academy Scientific Bulletin, Volume XX - 2017 - Issue 1

The journal is indexed in: PROQUEST / DOAJ / Crossref / EBSCOhost / INDEX COPERNICUS / DRJI / OAJI I

JOURNAL INDEX I I2OR / SCIENCE LIBRARY INDEX / Google Scholar I Academic Keys/ ROAD Open Access I

Academic Resources / Scientific Indexing Services / SCIPIO / JIFACTOR

[9] Flemming, B.W., „Side-scan sonar: a practical guide”, International Hydrographic Review, 53 (1): 6592; Monaco, 1976.

[10]Hildebrand, John, „Sources of Anthropogenic Sound in the Marine Environment”, Scripps Institution of Oceanography, University of California San Diego, 2004.

[11]Lurton, X., „An introduction to underwater acoustics. Principles and applications”, Springer, London, 2002.

[12] Shapiro, G. s.a., „Long term trends in the sea surface temperature of the Black Sea”, 2010.

[13] Shapiro, G. ş.a., „Predicted and observed variability in sound speed in the oceanic littoral”, University of Plymouth, 2010.

[14]Urban, Heinz G., „Handbuch der Wasserschalltechnik”, Editura STN ATLAS Elektronik GmbH, Bremen, 2002.

[15]Waite, A. D., „Sonar for Practising Engineers”, Wiley, 2002.

[16]Wernli, Robert L., „Low cost UUV'S for military applications: is the technology ready?”, Space and Naval Warfare Systems Center, San Diego, California, US, 2003.

[17]Hanganu M., Slămnoiu G., „Platformele de foraj marin românești și securitatea acestora”, Editura Universității Naționale de Apărare „Carol I", București, 2010 